\title{
The High-performance Work Environment and Employee Engagement to Face Changes in the Society 5.0 Era Millennial Workers
}

\author{
Noviaty Kresna Darmasetiawan ${ }^{1 *}$ \\ ${ }^{1}$ University of Surabaya, Surabaya, Indonesia \\ *Corresponding author.Email:noviatykds@gmail.com
}

\begin{abstract}
This research analyzes the influence of a high-performance work environment and employee engagement on millennials working in companies to face changes in the society 5.0 era. This research used mixed methods, i.e., quantitative methods that are equipped with qualitative methods. Variables tested were based on the dimensions expressed. Data were taken using questionnaires; the study respondents were millennial workers. The purpose of this study is to look at the influence of high-performance work environment factors on employee engagement in millennial workers to face changes in the society 5.0 era. The results show a significant influence between high-performance work factors on employee engagement in millennial workers to face changes in the society 5.0 era.
\end{abstract}

Keywords: high-performance work environment, employee engagement, change, society 5.0 era.

\section{INTRODUCTION}

Millennials enjoy new opportunities and develop skills. Like other generations, the millennial generation demands a work environment, has high self-confidence, and tends to be optimistic (Huntlay, Smola \& Sutton instead of Wong et al. 2008). Millennials are also said to be responsible and have an idea in decisions and actions (McCrindle \& Hooper instead of Wong et al. 2008). In addition, it is also explained that the millennial generation can see problems and opportunities from a new perspective, is more accepting of diversity, and likes working in teams than previous generations (Myers \& Sadaghiani 2010). Koester (2010) reveal that the millennial generation appreciates learning and development opportunities, credible and positive role models, and a balance between life and work (Kapoor \& Solomon 2011).

Macey et al. (2009) state that employee engagement is essential in creating shareholder value in an organization, especially in modern organizations with shifting organization to the millennial generation as employees or business people, more than just commitment, even though there are many assumptions that the millennial generation who becomes employees has lack employee engagement, lack loyalty, and work ethic. Individuals in this generation appear comfortable with changes and tend not to see job security as an essential factor in the workplace (Ardiansyah \& Darmasetiawan 2019). As an employee, the millennial generation enjoys new opportunities and always wants to develop their skills. On the other hand, Macey et al. (2009) states that a highperformance work environment will encourage employee engagement feelings that will affect employee engagement behavior (Koester 2010).

Companies $\mathrm{A}, \mathrm{B}$, and $\mathrm{C}$ are business organizations with millennial employees committed to carrying out various organizational changes to face the society 5.0 era. The companies carry out various changes in 
culture, structure, and technology because all the companies feel that these three changes are very much needed in the society 5.0 era, especially to create a highperformance work environment. Koester (2010) explains in detail that: "The sustainable organization must generate acceptable levels of economic performance, or it will not survive. It must also nurture social performance in its interaction with customers, suppliers, consumers, and other interest groups. Survival is also contingent on the firm's ability to achieve acceptable levels of environmental performance throughout the supply cycle from raw material procurement to post-consumption disposal."

The high-performance work environment proposed by Macey will be able to build principles for engagement, which include the capacity to engage, motivation to engage, freedom to engage, and know how to engage (Macey et al. 2009).

Furthermore, Macey et al. (2009) states that a high-performance work environment will create employee engagement feelings. Employee engagement feelings include feeling of urgency, feeling of being focused, feeling of intensity, and feeling of enthusiasm. Furthermore, it can be said that employee engagement feelings will be able to create employee engagement behavior. Hence, the following are research questions that will be answered in this study: (1) How does high-performance work environment affect employee engagement feelings of millennial generation employees who work in organization that implement changes to face the society 5.0 era?; (2) How do employee engagement feelings create employee engagement behavior of millennial generation employees who work in organization that implement changes to face the society 5.0 era ?; and (3) Why the high-performance work environment and employee engagement are needed to face changes in the society 5.0 era on millennial generation workers?

\subsection{High-performance work environment}

The work environment is one of the most important things that a company needs to pay attention to. It is something in the worker's environment that can affect a worker's work processes, such as temperature, humidity, lighting, and other things (Isyandi 2004).

Simajuntak (2003) stipulates that the work environment can be interpreted as something that employees live in, such as the environment where a person works and work methods, which can affect their works. Saydam (2000) says the work environment is a working infrastructure around employees who are carrying out work and can affect the work results.

Based on the definition, the work environment is very important for companies to pay attention to. Although it does not directly impact the processes in the company, it is considered to impact the psychological and physical condition of workers.

A high-performance work environment is a work environment that supports creativity, collaboration, and society which has become a necessity in recent years. A highperformance work environment supports the existence of teams in delivering quality products and services using innovative techniques.

\subsection{Employee engagement}

Employee engagement is a stable psychological state and the result of interactions between an individual and the workplace environment (Thomas 2007). According to Luthans and Peterson, engagement occurs when a person consciously has emotions connected to other people (Nusantria 2011). Kahn (1990) states that the construct of engagement is multidimensional, which is not only about emotionally but also physically and cognitively. According to Macey et al. instead of Armstrong 2017), engagement is an individual's goal and focus shown through work initiative, adaptability, effort, and persistence in achieving organizational goals. 
Employee engagement is a condition in which employees pay full attention to their work. Engagement is also defined as a positive attitude shown by employees towards the organization to give their best efforts to doing their job.

Furthermore, Macey et al. (2009) states that employee engagement will begin with the employee engagement feelings, and then employee engagement feelings will encourage employee engagement behavior.

Individual employee engagement feelings are felt in the form of feeling of urgency, feeling of being focused, feeling of intensity, and feeling of enthusiasm. Furthermore, employee engagement feelings will be shown in the form of employee engagement behavior. Employees who have employee engagement behavior will show behaviors of persistence, proactive, trying to expand the role (role expansion), and adaptability.

\subsection{Millennial generation workers}

Generations are an identified group, usually divided into years of birth and significant life events at the critical development stage experienced by a particular generation. Generational groups include those who share historical or social life experiences that influence the way individuals in that generation develop and differentiate one generation group from another (Wong et al. 2008).

Generation Y members include individuals born from 1982 to 2000 (Wong et al. 2008). Current generation Y labels include millennials, nexters, www generation, digital generation, E generation, echo generation, and Net generation (Tolbize 2008). Hart instead of Tolbize 2008) reveals that the millennial generation has grown up with technology and made technology a part of life. Ardiansyah \& Darmasetiawan (2018) illustrate that the millennial generation lacks loyalty and work ethic.

Individuals in this generation appear comfortable with changes and tend not to see job security as an important factor in the workplace. As an employee, millennial enjoys new opportunities and develops skills.
The millennial generation demands a work environment, has high self-confidence, and tends to be optimistic (Huntlay, Smola \& Sutton Sitat instead of Wong et al. 2008). Millennials are also said to be responsible and have an idea in decisions and actions (McCrindle \& Hooper instead of Wong et al. 2008). In addition, it is also explained that the millennial generation can see problems and opportunities from a new perspective, is more accepting of diversity, and likes working in teams than previous generations (Myers \& Sadaghiani 2010). Millennial generation appreciates learning and development opportunities, credible and positive role models, and a balance between life and work (Kapoor \& Solomon 2011).

\subsection{Changes in the society 5.0 era}

The concept of Society 5.0 is a refinement of previous concepts. In Society 1.0, humans were still in the era of hunting and familiar with writing. Society 2.0 was the era of agriculture where humans have started to recognize farming. Then Society 3.0 has entered the industrial era when humans have started using machines to support their daily activities. After that came the Society 4.0 that we experience today, namely humans who are familiar with computers to the internet and their application in life.

Society 4.0 allows us to access and share information on the internet. The internet is not just for sharing information but for living life. Society 5.0 creates a society that is human-centered and technology-based. $\mathrm{Hu}-$ mans have a role in the digital era, so a balance is needed between economic achievement and solving social problems.

Society 5.0 is intended to anticipate the Industrial 4.0 era, where the role of the community is still lacking. Society 5.0 is a human-centered concept of a technologybased society. The rapid development of technology, including the role of humans being replaced by the presence of intelligent robots, is considered to be able to integrate human roles. 
Society 5.0's artificial intelligence will transform big data in all aspects of life, and the Internet of Things will become new wisdom, namely humanistic values, and will be dedicated to improving human capabilities to open opportunities for humanity. This technological transformation will help humans to live a more meaningful life with the meaning of "humanizing human beings". Thus, in the era of Society 5.0, artificial intelligence is used to transform all data in all aspects of life. Therefore, for Indonesia, which has a large population but an unequal distribution of knowledge and education, Society 5.0 can be a complementary factor for success if appropriately implemented (Adi 2020).

\subsection{High-performance work environment and employee engagement to face changes in the society 5.0 era on millennial generation workers}

Basically, a high-performance work environment supports a creative, collaborative, and socially oriented work environment. The work environment has been continuously improved in recent years. While the previous generation distinguished clearly between the social and work environment, many believed that the work environment was enhanced by fostering a professional community with the same way of thinking. Millennials have redefined how work can be done and pushed the company's business forward.

In line with Myers \& Sadaghiani's (2020) statement, the millennial generation can see problems and opportunities from a new perspective, is more accepting of diversity, and likes working in teams than previous generations, a high-performance work environment is also a supportive work environment. Likewise, an organization that implements changes to face society 5.0 era is an organization with (1) clear goal settings, where effective leaders communicate a clear vision and establish realistic goals, ensuring that team members have adequate training; (2) maintaining open communication, in a highperformance workplace, leaders communi- cate regularly with subordinates to provide direction on what tasks need completion; (3) valuing diversity, recognizes the value that each team member brings, encourages each to contribute ideas, methods and opinions, even if they differ from his own, a positive work environment makes everyone on the team feel empowered to make suggestions and not fear reprisals. Each employee in a high-performance workplace feels valued. This contributes to high productivity; (4) Fostering collaboration, on highperformance teams, team members rely on each other for their skills and experience. When everyone gets rewarded consistently, these teams tend to work well together. With a sense of belonging and purpose, employees tend to work harder to fix complex problems, handle customer complaints, and maintain a competitive edge for the company in a complex global marketplace. Encouraging team members to develop their skills and knowledge fosters an atmosphere of growth and development that benefits the company and the employees.

On the other hand, an organizational change is also an organization that has managed to become a high-performance work environment to maintain overall sustainability. Furthermore, Macey (2009) states that a high-performance work environment will affect employee engagement feelings, and then employee engagement feelings will encourage employee engagement behavior.

\section{RESEARCH METHODS}

This research entails a focus on the topic of a high-performance work environment and employee engagement. The research used mixed methods, i.e., quantitative methods that are equipped with qualitative methods. It is a combination of explanatory and basic research with the purpose to understand the existing high-performance work environment and employee engagement feelings, employee engagement feelings, and employee engagement behavior in employee engagement and their effects and then used 
phenomenological approach, qualitative descriptive research, where the researcher knows the position at the time of data collection in the field and becomes the data interpreter (Moleong 2011), to analyze this topic through the experience, opinion, thoughts, and feelings of Companies A, B, and C employees who have implemented changes to face society 5.0 era practices in the organization. It is also supported by various theories of performance work environment, employee engagement feelings, and employee engagement behavior in employee engagement. The sampling technique used in this research was purposive sampling, that is, sampling technique from the data source with a certain consideration. (Sugiyono 2013).

Data collection techniques for a quantitative method used questionnaires, and a qualitative method used in-depth interviews. The data obtained from the questionnaire were selected first and then processed and analyzed using SPPS version 2.4. The results of this processing were then reprocessed using AMOS to provide a deeper analysis in accordance with the objectives and benefits of this study. Data processing used in this research began with a validity test and a reliability test.

Data analysis techniques for the qualitative method using (1) data reduction, data collected from the field in the form of results in-depth interview and observation, recorded in detail and thorough, then summarized, selected key points, focus on the things that are important and sought the theme and the pattern. After that, (2) displaying data after the data was reduced, then the next step was to perform the presentation of data. The presentation was done in the form of a brief description, making the chart, the relationship between categories, the flowchart in this study using narrative text. And the last step was (3) drawing conclusion/ verification is the withdrawal of conclusions and verification (according to Miles \& Huberman instead of Soegiyono 2013).

\section{RESULTS AND DISCUSSIONS}

From the results of quantitative research that has been done, it is proven that (1) a highperformance work environment affects employee engagement feelings for millennial generation employees who work in organizations that implement changes to face the society 5.0 era in a significant positive manner; (2) Employee engagement feelings can create employee engagement behavior among employees millennial generation who work in organizations that implement changes to face the society 5.0 era; and (3) The high-performance work environment and employee engagement are needed to face changes in the society 5.0 era on millennial workers.

Furthermore, from the results of the qualitative analysis, it is found that according to one person who is a millennial employee, with a position as a senior manager at Company A, Company A is a company or organization that has been carrying out changes to face the society 5.0 era. Companies that implement changes to face the society 5.0 era will strive to create business growth sustainably, have high-performance demands consistently. This is in line with the principle that a high-performance work environment is marked by setting clear goals. Furthermore, he said that to face the society 5.0 era; this company formulates the company's vision and mission, strategic policies, business processes, thus creating a solid culture in Company A, including the social and business aspects. In line with what was conveyed by millennial employees from Company A, it can be said that these conditions are in accordance with a high-performance work environment, namely a work environment that supports collaboration and is social to achieve profitability. Judging from employees' responses who are implementing the company's vision and mission, employees, including millennial employees, show enthusiasm, high initiative, and care for the company deeply through creative ideas put forward by employees for the Company A development. This is also supported by the 
results of qualitative research on a Company A millennial employee who work as a production employee, that the employee is always passionate about carrying out an energy-efficient production process, does not pollute the surrounding environment, and the production process optimally to produce products that are aware of the environment. Meanwhile, the third Company A millennial employee said that he is very excited to be involved in supporting the company by suggesting the idea of organizing a CSR program run by Company A, namely the idea of implementing CSR in the form of education about the environment and biodiversity from an early age at the primary, secondary school, to the university level.

A company B millennial employee said that his company has a strong culture, a clear direction, namely caring for environmental, economic, and social sustainability as a conscious unit in running a better life. According to him, the company's vision has been internalized, which makes them aware and eager to carry out their works to produce good quality products at an affordable price so that the sustainability and existence of the company can be maintained.

Moreover, a company $\mathrm{C}$ millennial employee said that company $\mathrm{C}$ had internalized all employees to align with the organization that implements changes to face Society 5.0 era. The employee voluntarily changes his behavior to be more environmentally friendly in accordance with the company's vision. Meanwhile, from an interview conducted with one of the Company $\mathrm{C}$ millennial employees, it is known that the employee is trying to develop his role as a technology intrapreneur, which is also a form of role expansion. This is consistent with the statement of Macey et al. (2009) that one of the characteristics of employees who have employee engagement is their willingness to take on role expansion and show persistence and proactive behaviors.

Therefore, this study shows that millennial employees who work in organizations that implement changes to face the society 5.0 era show employee engagement feelings, namely the feeling of urgency, feeling of being focused, feeling of intensity, and feeling of enthusiasm. Furthermore, this condition also shows employee engagement behavior. Millennial employees who work in an organization that implements changes to face society 5.0 show employee engagement behavior in the form of persistence, proactive, and adaptability behaviors in accordance with the demands of existing developments.

\section{CONCLUSION}

From the above discussion, it is concluded that (1) a high-performance work environment affects employee engagement feelings of millennial generation employees who work in an organization that implements changes to face the society 5.0 era positively and significantly, (2) Employee engagement feeling can create employee engagement behavior of millennial generation employees who work in an organization that implements changes to face the society 5.0 era it is positively significant, and (3) The highperformance work environment and employee engagement are needed to face changes in the society 5.0 era on millennial workers. Macey et al. (2009) states that the highperformance work environment will affect employee engagement feelings, which will encourage employee engagement behavior.

\section{REFERENCES}

Adi, S.W. 2020. Peluang dan Tantangan Generasi Millennial dalam Menghadapi Era Society 5.0. Solo: Jawa Pos-Radar.

Ardiansyah, N.I. \& Darmasetiawan, N.K. 2019. Psychological well-being and workplace relations gaps on generational differences. Advances in Social Science and Humanities Research Volume 308 (Atlantis press).

Amstrong, M. 2017. Handbook of Human Resource Management Practice. Thirteenth Edition. London: Kogan Page.

Isyandi, B. 2004. Manajemen Sumber Daya Manusia dalam Perspektif Global. Pekanbaru: Unri Press.

Kahn, W.A. 1990. Psychological conditions of personal engagement and disengagement at work. Academy of Management Journal 33: 692-724. 
Kapoor, C. \& Solomon, N. 2011. Understanding and managing generational differences in the workplace. Worldwide Hospitality and Tourism Themes 3(4): 308-318.

Koester, A. 2010. Workplace discourse. London: Continuum International Publishing Group.

Macey, Schneider, Barbera, Young. 2009. Employee Engagement, Tools for Analysis, Practice, and Competitive Advantage. UK: John Wiley \& Sons.

Moleong. L. J. 2011. Metode Penelitian Kualitatif. Bandung: PT. Remaja Rosdakarya.

Myers, K. \& Sadaghiani, K. 2010. Millennials in the workplace: A communication perspective on millennials' organizational relationships and performance. Journal of Business and Psychology 25(2): 225-238.

Nusantria, S. \& Suharnomo, 2011. Employee Engagement: Anteseden dan Konsekuensi Studi pada Unit CS PT. Telkom Indonesia Semarang. Undergraduate thesis, Universitas Diponegoro.

Simanjuntak, P.Y. 2003. Manajemen Hubungan Industrial. Jakarta: Pustaka Sinar Harapan.

Saydam. 2000. Manajemen Sumberdaya Manusia: Suatu Pendekatan Mikro. Jakarta: Djambaran.

Sugiyono. 2013. Metode penelitian kuantitatif, kualitatif, dan kombinasi (mixed methods). Fourth edition. Bandung: ALFABETA.

Tolbize. 2008. Generation differences in the workplace research and training center on community living, Minneapolis: University of Minnesota.

Thomas. 2007. A New Measurement Scale for Employee Engagement: Scale Development, Pilot Test, and Replication. Academy of Management Proceeding.

Wong, M. Gardiner, E. Lang, W. \& Coulon, L. 2008. Generational differences in personality and motivation. Journal of Managerial Psychology 23(8): 878-890. 